\title{
Berat badan lahir dan kejadian hipoglikemia pada neonatus
}

\author{
Raisha Ochi Melinda, ${ }^{1}$ Magdalena Wartono ${ }^{2}$
}

\begin{abstract}
ABSTRAK
\section{LATAR BELAKANG}

Salah satu penyebab kematian bayi baru lahir adalah kadar gula darah rendah (hipoglikemia) karena dapat menyebabkan kerusakan pada berbagai organ seperti otak. Neonatus dengan berat badan lahir (BBL) $\geq 3800 \mathrm{~g}$ atau $<2500 \mathrm{~g}$ sering mengalami hipoglikemia. Tujuan penelitian ini adalah untuk menentukan hubungan antara berat badan lahir dengan hipoglikemia pada bayi baru lahir.
\end{abstract}

\section{METODE}

Penelitian menggunakan desain cross sectional. Sampel pada penelitian ini adalah seluruh kelahiran di RSAL dr. Mintohardjo periode Januari-Juli 2019 sebanyak 71 bayi. Sampel dipilih secara consecutive non-random sampling. Data kadar gula darah dan berat badan lahir bayi diambil dari rekam medis. Hubungan kedua variabel diuji dengan uji Chi-square dengan tingkat kemaknaan $\mathrm{p}<0.005$.

\section{HASIL}

Penelitian menunjukkan sebanyak 16 bayi (22.5\%) memiliki BBL rendah, 41 bayi (57.7\%) memiliki BBL normal dan 14 bayi (19.7\%) memiliki BBL lebih. Pada penelitian ini bayi yang mengalami hipoglikemia sebanyak 32 bayi (45.1\%). Responden dengan berat badan lahir rendah dan mengalami hipoglikemia sebanyak 14 bayi (87.5\%). Sedangkan responden dengan berat badan lahir normal dan mengalami hipoglikemia sebanyak 8 bayi (19.5\%). Responden dengan berat badan lahir lebih dan mengalami hipoglikemia sebanyak 10 bayi (71.4). Hasil uji statistik menunjukkan nilai $\mathrm{p}=0.000$.

\section{KESIMPULAN}

Terdapat hubungan antara berat badan lahir bayi dan kejadian hipoglikemia pada bayi baru lahir.

Kata kunci: bayi baru lahir, berat badan lahir, hipoglikemia, neonatus
${ }^{1}$ Program Studi Kedokteran, Fakultas Kedokteran Universitas Trisakti, Jakarta, Indonesia ${ }^{2}$ Departemen Ilmu Kedokteran Kerja, Fakultas Kedokteran Universitas Trisakti, Jakarta, Indonesia

\section{Korespondensi:}

MagdalenaWartono

Departemen Ilmu Kedokteran

Kerja, Fakultas Kedokteran

Universitas Trisakti, Jakarta, Indonesia

Jalan Kyai Tapa (Kampus B)

Usakti, Grogol, Indonesia 11440

Email:

magdalena_w@trisakti.ac.id

J Biomedika Kesehat 2021;4(4):164169

DOI: 10.18051/JBiomedKes.2021. v4.164-169

pISSN: 2621-539X / eISSN: 2621-5470

Artikel akses terbuka (open access) ini didistribusikan di bawah lisensi Creative Commons Attribution 4.0 International (CC-BY 4.0) 


\section{ABSTRACT}

\section{Birth weight and incidence of neonatal hypoglycaemia}

\section{BACKGROUND}

Low blood sugar (hypoglycemia) is one of the causes of death because it can lead to various organ damage such as the brain. Hypoglycemia usually happened in newborns. Newborns that have a high risk in experiencing hypoglycemia are newborns weighing $\geq 3800 \mathrm{~g}$ or $<2500 \mathrm{~g}$. The purpose of this study was to determine the relationship between birth weight and hypoglycemia in newborns.

\section{METHODS}

The design of this study was cross sectional. Samples included all births at RSAL dr. Mintohardjo from January to July 2019 as many as 71 newborns. Sample chose by consecutive non-random sampling. Data on blood glucose levels and newborn's birth weight were taken from medical records. The relationship between the two variables was tested by Chi-square test with a significance level of $\mathrm{p}<0.005$.

\section{RESULTS}

The study showed as many as 16 newborns (22.5\%) had low BBL, 41 (57.7\%) had normal BBL and 14 (19.7\%) had higher BBL. As many as 32 newborns $(45,1 \%)$ experienced hypoglycemia. Respondents with low birth weight and experienced hypoglycemia were 14 newborns $(87,5 \%)$. Whereas the respondents with normal birth weight and experiencing hypoglycemia were 8 newborns $(19,5 \%)$. Respondents with high birth weight and experiencing hypoglycemia were 10 newborns $(71,4 \%)$. The $\mathrm{p}$-value obtained is $0.000(\mathrm{p}<0.05)$.

\section{CONCLUSION}

There is a relationship between birth weight and hypoglycemia incident in neonates.

Keywords: birth weight, hypoglycemia, newborns

\section{PENDAHULUAN}

Salah satu indikator yang sensitif untuk menilai kesehatan masyarakat di suatu negara adalah status kesehatan bayi. Profil Kesehatan Indonesia tahun 2019 menunjukkan bahwa Angka Kematian Neonatal (AKN) dan Angka Kematian Bayi (AKB) di Indonesia pada tahun 2017 adalah 15 dan 24 per 1000 kelahiran hidup, sedangkan target dari pemerintah Indonesia adalah Angka Kematian Neonatal bisa menjadi 10 per 1000 kelahiran hidup dan AKB menjadi 16 per 1000 kelahiran hidup pada tahun 2024. ${ }^{(1)}$

Masa yang paling rentan dari sepanjang kehidupan bayi adalah periode neonatal, yaitu periode 28 hari setelah lahir (empat minggu pertama kelahiran).(2) Menurut Kementerian Kesehatan RI, penyebab kematian pada neonatus adalah kondisi berat badan lahir rendah (BBLR), asfiksia, kelainan bawaan, sepsis, tetanus neonatorium, dan lainnya. ${ }^{(1)}$ Asfiksia dan sepsis ini dapat muncul sebagai akibat dari hipoglikemia neonatorum. ${ }^{(3)}$

Kadar gula darah yang rendah (hipoglikemia) dapat menyebabkan kerusakan pada berbagai organ seperti otak sehingga dapat menyebabkan terjadinya kematian pada neonatus, ${ }^{(4,5)}$ dengan demikian hal ini menjadi sesuatu yang perlu diperhatikan. Glukosa berperan penting pada bayi baru lahir karena glukosa adalah sumber cadangan energi dalam bentuk glikogen. Glikogen menyediakan 38 mol ATP (Adenosine triphosphate). ${ }^{(6)}$

Hipoglikemia sering terjadi pada bayi baru lahir. Bayi yang mengalami hipoglikemia biasanya tidak memiliki gejala (asimtomatik), sehingga kondisi ini mudah terlewatkan. Perlu diketahui bahwa pada neonatus kadar glukosa serum menurun dalam 1-3 jam pertama kehidupan, tetapi setelah itu akan meningkat secara spontan. ${ }^{(6)}$ Menurut penelitian yang dilakukan oleh Bromiker $\mathrm{R}$ et al prevalensi hipoglikemia pada bayi baru lahir adalah sebesar $12.1 \% .{ }^{(7)}$ Hypoglikemia pada neonatus merupakan faktor risiko dominan terjadinya cedera otak pada bayi baru lahir dan mengarah ke gangguan neurologis jangka panjang, seperti disabilitas intelektual, epilepsi, dan kebutaan. ${ }^{(8)}$ Hipoglikemia neonatorum adalah salah satu diagnosis paling umum yang memerlukan perawatan di unit perawatan intensif. (3)

Kontroversi masih sering terjadi terkait dengan konsentrasi glukosa darah dalam menentukan hipoglikemia pada neonatus. Kadar yang sering dipakai adalah kurang dari $30 \mathrm{mg} / \mathrm{dl}$ ( $1.65 \mathrm{mmol} / \mathrm{L})$ pada 24 jam pertama atau kurang dari $45 \mathrm{mg} / \mathrm{dl}$ setelahnya. ${ }^{(6)}$ Akan tetapi, karena adanya potensi terjadinya berbagai dampak penyakit maka banyak yang menggunakan kadar 
$<50 \mathrm{mg} / \mathrm{dL}$ sebagai patokan untuk dilakukan tata laksana. ${ }^{(6)}$ Faktor-faktor yang memengaruhi tingkat kadar gula darah pada bayi baru lahir adalah berat badan, usia gestasi, dan lain-lain. ${ }^{(6)}$ Penelitian oleh Yunarto Y mendapatkan bahwa bayi prematur adalah 6.5 kali dan bayi dengan berat badan lahir rendah $(<2500 \mathrm{~g})$ adalah hampir 3 kali berisiko untuk mengalami hipoglikemia dibandingkan dengan bayi dengan usia gestasi dan berat badan lahir normal. ${ }^{(9)}$ Kematian bayi baru lahir dengan hipoglikemia sering terjadi pada bayi yang lahir dengan berat $<1500 \mathrm{~g}$ (Very Low Birth Weight). ${ }^{(10)}$

World Health Organization (WHO) mendefinisikan berat lahir sebagai pengukuran berat badan pertama yang diperoleh dari bayi baru lahir. Menurut ukuran ini maka bayi baru lahir diklasifikasikan sebagai makrosomia, bila berat badan lahir lebih dari $4000 \mathrm{~g}$; berat badan lahir normal bila berat lahir berkisar antara 3000-3999 g; berat badan lahir kurang bila berat lahir berada di kisaran antara 2500 dan $2999 \mathrm{~g}$; dan berat badan lahir rendah (BBLR), jika beratnya kurang dari 2500 g. ${ }^{(11)}$ Berat badan lahir memiliki hubungan yang erat dengan kematian bayi, semakin rendah berat lahir dan usia kehamilan, semakin besar kemungkinan kematian pada tahun pertama kehidupan. ${ }^{(11)}$ Pada bayi dengan BBLR, penurunan berat badan bayi dapat terjadi setiap saat sebagai akibat dari asupan Air Susu Ibu (ASI) yang kurang karena ketidakmampuan bayi untuk menghisap ASI. Dengan demikian besar kemungkinan kadar gula darah yang abnormal bisa terjadi pada bayi yang lahir dengan BBLR. ${ }^{(12)}$

Pada penelitian yang dilakukan oleh Bhand et al. menyimpulkan bahwa faktor bayi yang berkaitan dengan hipoglikemia adalah berat lahir rendah, usia gestasi kecil, makrosomia, gangguan pernapasan, sepsis, hipotermia, kelainan kongenital jantung dan pemberian makan yang inadekuat, dan faktor risiko ibu seperti eklampsia, diabetes mellitus pada ibu, dan penggunaan obat pada ibu.

(13) Sedangkan pada penelitian yang dilakukan oleh Hosagasi et al. menyimpulkan bahwa tidak ada hubungan antara berat lahir bayi, jenis kelamin, cara persalinan dan 5 menit APGAR Score dengan kejadian hipoglikemia. ${ }^{(14)}$ Tujuan dari penelitian ini adalah untuk menentukan hubungan antara berat badan lahir dengan hipoglikemia pada bayi baru lahir.

\section{METODE}

Penelitian ini menggunakan metode cross sectional, dengan subjek penelitian seluruh kelahiran di RSAL dr. Mintohardjo periode Januari sampai Juli 2019. Penelitian dilaksanakan pada bulan Agustus sampai November 2019, dengan besar sampel 71 bayi. Kriteria inklusi dalam penelitian ini adalah semua bayi yang lahir pada periode Januari sampai Juli 2019 RSAL dr. Mintohardjo. Kriteria eksklusi, yaitu bayi yang memiliki ibu yang menderita diabetes melitus, preeklampsi, eklampsi, atau oligohidramnion; bayi baru lahir yang mengalami anemia hemolitik, defek kongenital, asfiksia, prematuritas, atau hipotermia. Teknik pengambilan sampel adalah consecutive non-random sampling. Data merupakan data sekunder dengan melakukan pencatatan hasil pengukuran kadar gula darah 24 jam pertama dan disebut mengalami hipoglikemia bila kadar gula darah $<47.5 \mathrm{mg} / \mathrm{dL}$ dan tidak mengalami hipoglikemia bila kadar gula darah $\geq$ $47.5 \mathrm{mg} / \mathrm{dL}$. Selain itu, juga dilakukan pencatatan berat badan lahir yang ada di rekam medis. Hubungan kedua variabel diuji dengan uji Chisquare dengan tingkat kemaknaan $\mathrm{p}<0.005$. Penelitian ini telah lolos kaji etik oleh Komisi Etik Riset Fakultas Kedokteran Universitas Trisakti dengan nomor kaji etik 80/KER-FK/VII/2019.

\section{HASIL}

Tabel 1. Distribusi frekuensi karakteristik dasar responden

\begin{tabular}{lcc}
\hline \multicolumn{1}{c}{ Variabel } & n & \% \\
\hline Jenis Kelamin & & \\
Laki-laki & 33 & 46.4 \\
Perempuan & 38 & 53.5 \\
Berat Badan Lahir & & \\
Lebih $(\geq 3800$ gram $)$ & 14 & 19.7 \\
Normal $(2500 \mathrm{~g}-<3800 \mathrm{~g})$ & 41 & 57.7 \\
Rendah $(<2500 \mathrm{~g})$ & 16 & 22.5 \\
Hipoglikemia & & \\
Ya $(<47.5 \mathrm{mg} / \mathrm{dL})$ & 32 & 45.1 \\
Tidak $(\geq 47.5 \mathrm{mg} / \mathrm{dL})$ & 39 & 54.9 \\
\hline
\end{tabular}

Keterangan: $\mathrm{n}=$ frekuensi; $\%=$ persentase

Berdasarkan hasil penelitian bayi dengan berat badan lahir normal adalah yang paling banyak, yaitu $57.7 \%$ sedangkan bayi dengan berat badan lahir rendah adalah sebanyak 16 bayi 
Tabel 2. Hubungan antara berat badan lahir bayi dan hipoglikemia

\begin{tabular}{|c|c|c|c|c|c|}
\hline \multirow[t]{2}{*}{ Variabel } & \multicolumn{5}{|c|}{ Hipoglikemia $(n=71)$} \\
\hline & Ya & $(\%)$ & Tidak & $(\%)$ & $\mathbf{p}^{*}$ \\
\hline \multicolumn{6}{|l|}{ Berat Badan Lahir Bayi } \\
\hline Lebih & 10 & 71.4 & 4 & 28.6 & 0.000 \\
\hline $\begin{array}{l}\text { Normal } \\
\text { Rendah }\end{array}$ & $\begin{array}{l}8 \\
14\end{array}$ & $\begin{array}{l}19.5 \\
87.5\end{array}$ & $\begin{array}{c}33 \\
2\end{array}$ & $\begin{array}{l}80.5 \\
12.5\end{array}$ & \\
\hline
\end{tabular}

*Uji Chi-square

(22.5\%). Bayi yang mengalami hipoglikemia adalah sebanyak 32 bayi (45.1\%).

Hasil tabulasi silang pada Tabel 2 menunjukkan responden dengan berat badan lahir rendah dan mengalami hipoglikemia sebanyak 14 bayi $(87.5 \%)$. Responden dengan berat badan lahir normal dan mengalami hipoglikemia sebanyak 8 bayi (19.5\%). Sedangkan responden dengan berat badan lahir lebih dan mengalami hipoglikemia sebanyak 10 bayi (71.4\%). Hasil uji statistik menunjukkan nilai $\mathrm{p}=0.000(\mathrm{p}<0.005)$ yang menunjukkan adanya hubungan antara berat badan lahir bayi dengan kejadian hipoglikemia pada bayi baru lahir.

\section{PEMBAHASAN}

Responden pada penelitian ini adalah 71 bayi. Terdapat 33 bayi laki-laki dan 38 bayi perempuan. Dari semua responden yang mengalami hipoglikemia adalah 32 bayi (45.1\%). Angka kejadian ini tidak berbeda jauh dengan penelitian yang dilakukan oleh Kumar et al yang menunjukkan kejadian hipoglikemia pada bayi baru lahir adalah $51 \%{ }^{(15)}$ Sedangkan hasil yang berbeda didapatkan pada penelitian yang dilakukan oleh Singh et al di mana angka kejadian hipoglikemia hanya $15.2 \%$. $^{(16)}$ Perbedaan ini terjadi karena adanya perbedaan definisi dari variabel tergantung. Pada penelitian yang dilakukan oleh Singh et al (16) dikatakan hipoglikemia apabila kadar gula darah bayi adalah $<40 \mathrm{mg} / \mathrm{dL}$, sedangkan pada penelitian ini penentuan hipoglikemia adalah $<47.5 \mathrm{mg} / \mathrm{dL}$. Hipoglikemia merupakan kejadian yang sering terjadi pada bayi baru lahir, sehingga pemantauan terhadap bayi baru lahir sebaiknya dilakukan tiap rumah sakit karena bisa menimbulkan komplikasi apabila terlambat dideteksi dan di tata laksana. ${ }^{(17)}$

Berdasarkan hasil analisis bivariat didapatkan bahwa bayi dengan berat badan lahir rendah yang mengalami hipoglikemia adalah paling banyak dibandingkan dengan bayi dengan berat badan lahir normal dan lebih. Hasil penelitian ini sama dengan yang ditemukan oleh Saini A et al. di mana $58.3 \%$ bayi dengan berat lahir rendah mengalami hipoglikemia. ${ }^{(18)}$ Dari penelitian yang dilakukan oleh Amarendrajuga didapatkan bahwa bayi dengan berat badan lahir rendah insidensi mengalami hipoglikemia adalah terbanyak (72.22\%) jauh lebih tinggi dari berat badan lahir normal. ${ }^{(19)}$ Semakin rendah berat badan lahir seorang bayi semakin tinggi risiko bayi tersebut mengalami hipoglikemia. Didapatkan juga pada bayi berat lahir rendah, $24 \%$ di antaranya mengalami hipoglikemia berkelanjutan di hari pertama lahir. ${ }^{(19)}$ Bayi dengan berat lahir kurang dari 1800 gr memiliki daya hisap dan menelan yang inaktif, lemah dan tidak terkoordinasi dengan baik karena sistem saraf pusat yang belum mature. Hal ini menyebabkan asupan nutrisi menjadi kurang. Selain itu, cadangan glikogen hepatik pada bayi-bayi tersebut juga rendah. Kedua hal ini menyebabkan kecenderungan untuk mengalami hipoglikemia. ${ }^{(18)}$

Pada bayi baru lahir dengan berat normal, beberapa di antaranya mengalami hipoglikemia, tetapi tidak sebanyak pada bayi dengan berat lahir rendah atau lebih. Pada penelitian yang di lakukan De A et al. secara keseluruhan kejadian hipoglikemia pada bayi dengan BBL normal hanya $14 \%$ dari 150 bayi lahir, angka ini tidak berbeda jauh dengan penelitian ini. ${ }^{(20)}$ Mereka juga mengevaluasi peran menyusui dini pada hipoglikemia dan juga menilai dampak pemberian ASI eksklusif hingga usia 48 jam pada bayi dengan berat lahir normal yang sehat dan bayi berat lahir rendah, termasuk bayi prematur dan kecil untuk kehamilan usia bayi. Mereka menyimpulkan bahwa kejadian hipoglikemia secara signifikan 
terjadi pada neonatus yang kegiatan menyusui tertunda daripada menyusui dini $(64 \%$ vs $17 \%$; $\mathrm{p}<0.001) .{ }^{(20)}$ Menurut rekomendasi dari American Academy of Pediatrics dan WHO, skrining glukosa darah harus disediakan untuk neonatus yang berisiko atau bergejala. Bayi baru lahir yang sehat dan cukup bulan mengalami penurunan glukosa darah fisiologis yang normal dan mampu mengoreksi sendiri setelah 1-3 jam kehidupan. ${ }^{(21)}$

Pada penelitian ini ditemukan 10 dari 14 bayi baru lahir dengan berat badan lebih mengalami hipoglikemia. Studi Patel $\mathrm{P}$ et al. menemukan $20 \%$ bayi makrosomia dan $18 \%$ bayi dengan berat lahir lebih besar dari usia gestasi mengalami hipoglikemia pada 24 jam pertama dan normal kembali saat 48 jam berikutnya. (22) Kayode-Adedeji B yang meneliti 290 bayi makrosomia mendapatkan bahwa hipoglikemia dan ikterik merupakan masalah yang sering muncul dan biasanya berkaitan dengan diabetes gestational pada ibu. ${ }^{(23)}$

Hasil analisis bivariat pada penelitian ini menunjukkan adanya hubungan antara berat badan lahir bayi dan kejadian hipoglikemia. Hal ini sesuai dengan penelitian oleh Yunarto $Y$ yang mendapatkan risiko terjadinya hipoglikemia pada neonatus berhubungan dengan berat lahir terutama pada bayi dengan berat badan lahir rendah. ${ }^{(9)} \mathrm{Hal}$ ini berbeda dengan penelitian yang dilakukan oleh Hosagasi $\mathrm{N}$ et al. ${ }^{(14)}$ yang menyatakan bahwa tidak ditemukannya hubungan antara berat lahir terhadap kejadian hipoglikemia pada bayi baru lahir. Tidak ada perbedaan kejadian hipoglikemia antara bayi dengan berat lahir lebih, normal dan rendah karena normal bayi baru lahir di awal 24 jam kelahiran akan mengalami penurunan kadar gula darah nya $\leq 30 \mathrm{mg} / \mathrm{dL}$, selanjutnya akan semakin turun dan beberapa jam kemudian akan naik menuju angka kadar gula darah normal bayi. Hal ini terjadi pada hampir semua bayi yang baru lahir dan tidak dipengaruhi oleh faktor-faktor tertentu termasuk berat badan lahir. ${ }^{(24)}$ Pada penelitian ini data kadar gula darah yang diambil adalah kadar yang diukur pada saat 1 jam pertama setelah bayi lahir karena apabila pada jam pertama hasil pemeriksaan menunjukkan kadar gula darah rendah maka bayi akan langsung dianggap mengalami hipoglikemia dan diberikan tata laksana yang tepat, sehingga pada jam-jam berikutnya kadar gula darah bayi sudah tidak bisa menjadi acuan untuk menentukan bayi tersebut hipoglikemia atau tidak.

Hipoglikemia pada bayi baru lahir atau neonatus kadang tidak menunjukkan gejala, namun bisa berdampak terjadinya kelainan atau kecacatan pada susunan saraf pusat. ${ }^{(9)}$ Oleh sebab itu, berdasarkan hasil dari penelitian ini di mana berat badan lahir baik normal, kurang atau lebih berhubungan dengan kejadian hipoglikemia maka dalam praktik sehari-hari pemeriksaan kadar gula darah pada bayi baru lahir perlu dipertimbangkan.

Penelitian ini memiliki beberapa

keterbatasan, yaitu kadar gula darah di waktu yang lain selain hasil pemeriksaan satu jam pertama tidak ditemukan di rekam medis, sehingga tidak dapat ditentukan apakah hipoglikemia pada bayibayi yang baru lahir tersebut terus berlanjut atau tidak.

\section{KESIMPULAN}

Pada penelitian ini didapatkan prevalensi hipoglikemia pada bayi baru lahir adalah $45.1 \%$. Jumlah bayi dengan berat badan lahir rendah yang mengalami hipoglikemia adalah yang paling tinggi dibandingkan bayi dengan berat badan lahir normal dan lebih. Didapatkan hubungan antara berat badan lahir dengan kejadian hipoglikemia pada bayi baru lahir. Disarankan untuk penelitian selanjutnya dapat melihat pengaruh waktu terhadap kejadian hipoglikemia dan hubungannya dengan berat badan lahir serta memperluas populasi penelitian sehingga berat badan lahir diharapkan bisa menjadi predictor terjadinya hipoglikemia pada bayi baru lahir.

\section{KONFLIK KEPENTINGAN}

Tidak didapatkan konflik kepentingan pada penelitian ini.

\section{REFERENSI}

1. Kementrian Kesehatan RI. Profil Kesehatan Indonesia [Internet]. Kemenkes RI; 2019. Available from: https://pusdatin.kemkes.go.id/ resources/download/pusdatin/profil-kesehatanindonesia/Profil-Kesehatan-indonesia-2019.pdf

2. Roro EM, Tumtu MI, Gebre DS. Predictors, causes, and trends of neonatal mortality at Nekemte Referral Hospital, east Wollega Zone, western Ethiopia (2010-2014). Retrospective cohort study. PLoS ONE. 2019;14(10):e0221513. doi: 10.1371/ journal.pone.0221513.

3. Alsaleem M, Saadeh L, Kamat D. Neonatal Hypoglycemia: A Review. Clinical Pediatrics. 2019;58(13):1381-1386. doi: $10.1177 / 0009922819875540$. 
4. Kaiser J, Bai S, Gibson N, et al. Association Between Transient Newborn Hypoglycemia and Fourth-Grade Achievement Test Proficiency: A Population-Based Study. JAMA Pediatr. 2015;169(10):913-21. doi: 10.1001/ jamapediatrics.2015.1631.

5. McKinlay C, Alsweiler J, Ansell J, et al. Neonatal Glycemia and Neurodevelopmental Outcomes at 2 Years. N Engl J Med. 2015;373(16):1507-18. doi: 10.1056/NEJMoa1504909.

6. Stomnaroska-Damcevski O, Petkovska E Jancevska S, et al. Neonatal Hypoglycemia: A Continuing Debate in Definition and Management. Pril (Makedon Akad Nauk Umet Odd Med Nauki). 2015;36(3):91-7. doi: 10.1515/prilozi-2015-0083.

7. Bromiker R, Perry A, Kasirer Y, et al. Early neonatal hypoglycemia: incidence of and risk factors. A cohort study using universal point of care screening. J Matern Fetal Neonatal Med. 2019;32(5):786792. doi: 10.1080/14767058.2017.1391781.

8. Fong CY, Harvey AS. Variable outcome for epilepsy after neonatal hypoglycaemia. Dev Med Child Neurol. 2014;56(11):1093-9. doi: 10.1111/ dmen.12496.

9. Yunarto Y, Sarosa G. Risk factors of neonatal hypoglycemia. Paediatrica Indonesiana. 2019;59(5):252-6. doi: 10.14238/pi59.5.2019.2526

10. Fendler W, Walenciak J, Mlynarski W, et al. Higher glycemic variability in very low birth weight newborns is associated with greater early neonatal mortality. J Matern Fetal Neonatal Med. 2012;25(7):1122-6. doi: 10.3109/14767058.2011.624220.

11. Vilanova CS, Hirakata VN, de Souza Buriol VC et al. The relationship between the different low birth weight strata of newborns with infant mortality and the influence of the main health determinants in the extreme south of Brazil. Popul Health Metrics. 2019;17(15). doi: 10.1186/s12963-019-0195-7.

12. Redkar R, Karkera P, Krishnan J, et al. Subtotal Pancreatectomy for Congenital Hyperinsulinism: Our Experience and Review of Literature. Indian J Surg. 2015;77(Suppl 3):778-82. doi: 10.1007/ s12262-013-0999-9.

13. Bhand S, Sheikh F, Siyal A, et al. Neonatal hypoglycemia; presenting pattern and risk factor of neonatal hypoglycemia. The Professional Medical Journal. 2014;21(4):745-749.

14. Hosagasi N, Aydin M, Zenciroglu A, et al. Incidence of hypoglycemia in newborns at risk and an audit of the 2011 American academy of pediatrics guideline for hypoglycemia. Pediatr Neonatol. 2018;59(4):368-374. doi: 10.1016/j. pedneo.2017.11.009

15. Kumar TJ, Vaideeswaran M, Seeralar AT. Incidence of hypoglycemia in newborns with risk factors. Int J Contemp Pediatr 2018;5:1952- 5.

16. Singh M, Devi T, Devi T, et al. Hypoglycemia in newborn in Manipur. J Med Soc. 2014;28(2):108.

17. Flavin M, Grewal $\mathrm{K}, \mathrm{Hu} \mathrm{L}$. Hypoglycemia in newborns with no pre-identified risk factors. Montreal: Canadian Paediatric Society Annual Meeting; 2014 Jun 25-28.

18. Saini A, Gaur BK, Singh P. Hypoglycemia in low birth weight neonates: frequency, pattern, and likely determinants. Int J Contemp Pediatr. 2018;5:52632. doi: 10.18203/2349-3291.ijcp20180548

19. Amarendra M, Sethi R, Pericherla V. Incidence of hypoglycaemia within 72 hours after birth in low birth weight babies who are appropriate for gestational age. IJCP. 2018;5(3). doi: 10.18203/2349-3291.ijcp20181518

20. De AK, Biswas R, Samanta M, et al. Study of blood glucose level in normal and low birth weight newborns and impact of early breast feeding in a tertiary care centre. Ann Nigerian Med. 2011;5:538

21. Samayam P, Ranganathan PK, Kotari UD, et al. Study of Asymptomatic Hypoglycemia in Full Term Exclusively Breastfed Neonates in First 48 Hours of Life. J Clin Diagn Res. 2015;9(9):SC07SC10. doi:10.7860/JCDR/2015/14971.6610

22. Patel P, Gogoi PR, Deb S, et al. Hypoglycemia in exclusively breastfed high-risk neonates-a hospital-based study. Int J Pediatr Res. 2020;6:066. doi: 10.23937/2469-5769/1510066

23. Kayode-Adedeji B, Egharevba O, Omoregbee $H$. Prevalence of fetal macrosomia and neonatal complications in a Nigerian suburban hospital: a five year study. J Pediatr Neonat Individual Med. 2018;7(1):e070120. doi: 10.7363/070120.

24. Holtrop PC. The frequency of hypoglycemia in full-term large and small for gestational age newborns. Am J Perinatol. 1993 Mar;10(2):150-4. doi: $10.1055 / \mathrm{s}-2007-994649$. 